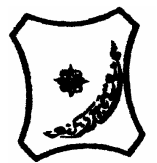

Bayero Journal of Pure and Applied Sciences, 4(2): 45 - 52

Received: October, 2010

Accepted: October, 2011

ISSN $2006-6996$

\title{
SPATIAL AND TEMPORAL VARIATION OF ZOOPLANKTONIC FAUNA COMPOSITION AND DISTRIBUTION IN THE JAKARA-GETSI RIVER SYSTEM, KANO, NIGERIA
}

\author{
${ }^{*}{ }^{1}$ Imam, T.S., ${ }^{2}$ Balarabe, M.L. and ${ }^{1}$ Oyeyi, T.I. ${ }^{1}$ \\ ${ }^{1}$ Department of Biological Sciences, Bayero University, Kano, Nigeria \\ ${ }^{2}$ Department of Biological Sciences, Ahmadu Bello University, Zaria, Nigeria \\ *Correspondence author: tsimam2001@yahoo.com
}

\begin{abstract}
This study aimed at assessing the spatial and temporal variation of zooplanktonic fauna composition and distribution in the Jakara-Getsi River system, Kano. Sampling was conducted monthly for 12 months (January, to December, 2009). Three sampling sites were selected, they are: Sampling Site A; Jakara River, Sampling Site B: Getsi River and Sampling Site C: Magami (Confluence). Zooplankton Samples were collected using plankton net by vertical haul. Samples were put into labeled $100 \mathrm{~mL}$ bottle. Water physicochemical parameters determined were temperature, pH, transparency, dissolved oxygen (DO) and 5-day biochemical oxygen demand. Electrical conductivity (EC) were conducted according to standard operating procedures, readings obtained were recorded and consequently analysed. Results showed highest species richness of 20 spp recovered at site $A$, with higest zooplankton density of $691.28 \mathrm{org} / L$, while lowest species richness was recorded at site C, 13 species with zooplankton density of $443.19 \mathrm{org} / \mathrm{L}$. Species richness accrdig to taxa showed highest was highest among the Protozoa with 12 spp., with lowest species richness of one specie each among the Rotifera, and nematode. There is observed bimodal fluctuation in zooplankton density at the three sites. At site A, double maxima were recorded in the months of February and December, $199.3 \mathrm{org} / \mathrm{L}$ and 109.77org/L respectively. At site $B$, there were observed maxima in the months of February and April, $138.22 \mathrm{org} / \mathrm{L}$ and $60.97 \mathrm{org} / \mathrm{L}$ respectively. Kendall's tau-b correlation between physico-chemical parameters was positive between $D O$ and transparency at $P \leq 0.05$ (2-tailed). There was negative Kendall's tau-b correlation EC and pH at $P \leq 0.05$ (2-tailed). There was also positive correlation in zooplankton density between sites $A$ and $B$ at $P \leq 0.05$ (2-tailed), likewise between sites $A$ and $C$ at $P \leq 0.05$ (2-tailed).
\end{abstract}

Keywords: Jakara-Getsi, physico-chemical, spatial, temporal, zooplanktonic fauna

\section{INTRODUCTION}

Zooplankton refers to the animal potion of plankton; the animal community in marine and fresh-water situations which floats free in the water, independent of shore and bottom, moving passively with the currents (Verna and Agarwal, 2007). Zooplanktonic fauna are the major mode of energy transfer between the phytoplankton and the fish (Howick and Wilhm, 1984). The diversity of an aquatic system refers to the richness of biological variation in terms of the number of species found herein. Study of zooplanktonic fauna composition and distribution could serve as very useful indices of water quality. Zooplankton have long been used as indicator of water quality, because they respond to environmental factors such as water chemistry, shoreline disturbances and watershed land use, as well as levels of vertebrate and invertebrate predation Zooplankton composed of the protozoa, the crustaceans especially the cladoceran and copepods, the nematodes together with the eggs, larvae and pupae of aquatic insects as well as the annelids (Imam, 2010).

Jakara-Getsi River systems is part of the north-eastern watershed of the Kano metropolis, which carries urban domestic wastewater as well as industrial efflents from the Bompai industrial estate. Studies have shown that the river system is highly contaminated with both organic and inorganic pollutants (Imam, 2010; Binns et al., 2003; Bichi and Anyata, 1999).

Empirical evidence from the Kano city suggests that there is currently much reason for concern as industrial and domestic toxins are reaching dangerously high levels, thus, affecting the biodiversity in terms of aquatic species richness and diversity. During the dry season, flow of Jakara-Getsi river system is almost entirely made-up of sewage and industrial wastewater discharges (1978; Bichi, 1993).

There is paucity of information on zooplankton composition and distribution based on spatial as well as temporal variation of the river system despite its high levels of pollution. This study aimed at assessing the spatial and temporal variation of zooplanktonic fauna composition and distribution in the Jakara-Getsi River system, Kano.

\section{MATERIALS AND METHODS}

Study Area and Sampling sites

Kano metropolis $\left(12^{0} \mathrm{~N}, 8^{0} 5-8^{0} 75 \mathrm{E}\right)$ is an urban closed settle zone made up of tripartite urban centers of Kano city only, capital of Kano state (Figure 1), Kano township and Waje district with its various subdivisions. 
It is a key area of modern Nigeria, and one of the largest rural-urban complexes in Africa (Mukhtar et al., 2010). Sampling was conducted monthly for 12 months (January, 2009 to December, 2009). Three sampling sites were selected, they are:

\section{Sampling Site A: Jakara River}

This is located on Jakara River, at Nomansland off Zungeru road $\left(11^{0} 58.822 \mathrm{~N}, 008^{0} 28.412 \mathrm{E}\right)$ in a high density residential area. Substantial vegetable production takes place on both banks of Jakara River, and crops are irrigated by water from the Jakara channel, which forms northern watershed of Kano, which flows through the Kano old city (Birni), specifically starting from Aminu Kano Way, Municipal, Gwale, Dala, Fagge, Sabon Gari and Gwagwarwa. The Jakara River serves as the main drain for built up areas along the way. Most of the wastewater entering the irrigation channel comes from residential sources (Figure 2).

\section{Sampling Site B: Getsi River}

This site is located $100 \mathrm{~m}$ away from Kwana Hudu Bridge on the River Getsi $\left(12^{0} 05.930 \mathrm{~N}, 008^{0} 37.807 \mathrm{E}\right)$. The river receives effluents from the Bompai industrial Estate. A significant proportion of the factories in operation at the industrial estate are tanneries and textile mills. Field observations revealed that PVC pipes used underground for supplies of domestic potable water in the settlements surrounding Bompai which passes across the Getsi river (Figure 2).

\section{Sampling Site C: Magami (Confluence)}

The site is located within 5 meters away from the confluence of Jakara and Getsi rivers Getsi $\left(12^{0}\right.$ $\left.03.159 \mathrm{~N}, 008^{0} 32.689 \mathrm{E}\right)$. Where industrial effluents from the River Getsi and domestic wastewater from the Jakara River mix (Figure 2).

\section{Water Physico-chemical Determination}

- Surface Water Temperature: was determined using mercury-in glass thermometer by dipping it into water for 5 seconds, removed and reading conducted immediately and recorded (APHA, 2005).

- pH, and Elecrical Conductivity: were measured using pH/EC/TDS meter HANNA 3100 Model by dipping the probes into the water untill the screen showed a fixed reading (HANNA Instruments,2004)

- DO: was determined using DO meter, in which the probe was inserted into the water until DO reading in $\mathrm{ppm}(\mathrm{mg} / \mathrm{L})$ was recorded, then Oxygen saturation was read off in percentage (HANNA Instruments,2004).

- BOD5: was measured after collecting the samples into a labeled $250 \mathrm{~mL}$ brown bottle, kept in incubator at Research laboratory at $21^{\circ} \mathrm{C}$ for 5 days, then DO was measured again. BOD5 was obtained by subtracting the 5-day Do reading from the 0 -day DO reading (APHA, 2005).

- Transparency: was measured using $20 \mathrm{~cm}$ diameter Secchi disc, which was dipped into the water till the disc visibly disappeared, the depth was then recorded, and as it was removed, the depth at which it first appeared was also recorded, actual reading was obtained by taking the average of the two readings(APHA,2005).

\section{Zooplankton Samples Collection}

Zooplankton Samples were collected using plankton net by vertical haul. Samples were put into labeled $100 \mathrm{~mL}$ bottle (APHA, 2005). Some samples were preserved by dropping $4 \%$ Formalin for identification and photomicrograph.

\section{Concentration Technique: Sedimentation}

The obtained sample from the plankton net was kept undisturbed for sedimentation to take place at $1 \mathrm{hr}$ settling per $\mathrm{mm}$ of column depth according to the protocol of APHA (2005). The advantage of sedimentation method over filtration and centrifugation are that it is non selective as compared to filtration and it is non destructive as in centrifugation. The supernatant was decanted in order to obtain desired volume. The concentrated sample was stored in a closed labeled vial bottle for identification and counting of zooplanktons (APHA, 2005).

\section{Zooplankton Enumeration and Density Estimation}

Obtained using the following formula:

No. of Orgs/m3: C x VI/ VII x VIII; Where: $C=$ No. of organisms counted

$\mathrm{VI}=$ concentrated sample $(\mathrm{mL}) ; \mathrm{VII}=$ Volume counted $(\mathrm{mL}) ;$ VIII $=$ Volume of water of the grab sample(m3)

To obtain Viii: the following formula was used: VIII $=n r 2 d$; Where: $n=22 / 7 ; \quad r=$ radius of plankton orifice $(12.5 \mathrm{CM}) ; \mathrm{d}=$ depth at which grab sample was obtained (APHA, 2005).

\section{Biodiversity Indices}

Saprobic Index: $\mathrm{S}=\Sigma(\mathrm{s} . \mathrm{h}) / \quad \mathrm{h}$ (Zladaçek and Tuçek,1975); Where: s=saprobity class(1-4), $h=$ abundance of $\operatorname{spp}(1-9)$. NB: It estimates level of organic loading of the water.

Jaccard Similarity Index(JSI): J= C/N1+N2-C (Allaby, 1999)

Where: $\mathrm{C}=$ No. of taxa shared between a pair of site; N1 and N2: No. of spp in each of the two sites. NB:It corelates two sites in terms of evenness.

Margalef Index: $D=(S-1) / \operatorname{lnN}$ (Margalef, 1958; SDRIV, 2010)

Where:S=No. of spp, $\ln N=$ Natural log of Total No. of Individuals. NB: It increases with increase in No. of spp.

Berger-Parker Dominance Index: $\mathrm{CDI}=\mathrm{Y} 1+\mathrm{Y} 2 /$ $Y$ (Maiti, 2004); Where: $Y 1=$ abundance of the most dominant spp; $\mathrm{Y} 2=$ abundance of the 2nd most dominant spp; $Y=$ total abundance of all spp at the site.

\section{Statistical Analysis}

SPSS statistical software version 15 was employed in the analysis of data obtained, which include variables of zooplanktonic fauna. Student T-test was used to test for significant difference between the variables, likewise Kendall's tau-b correlation was also utilised in the case of testing for any significant correlation between the variables. 


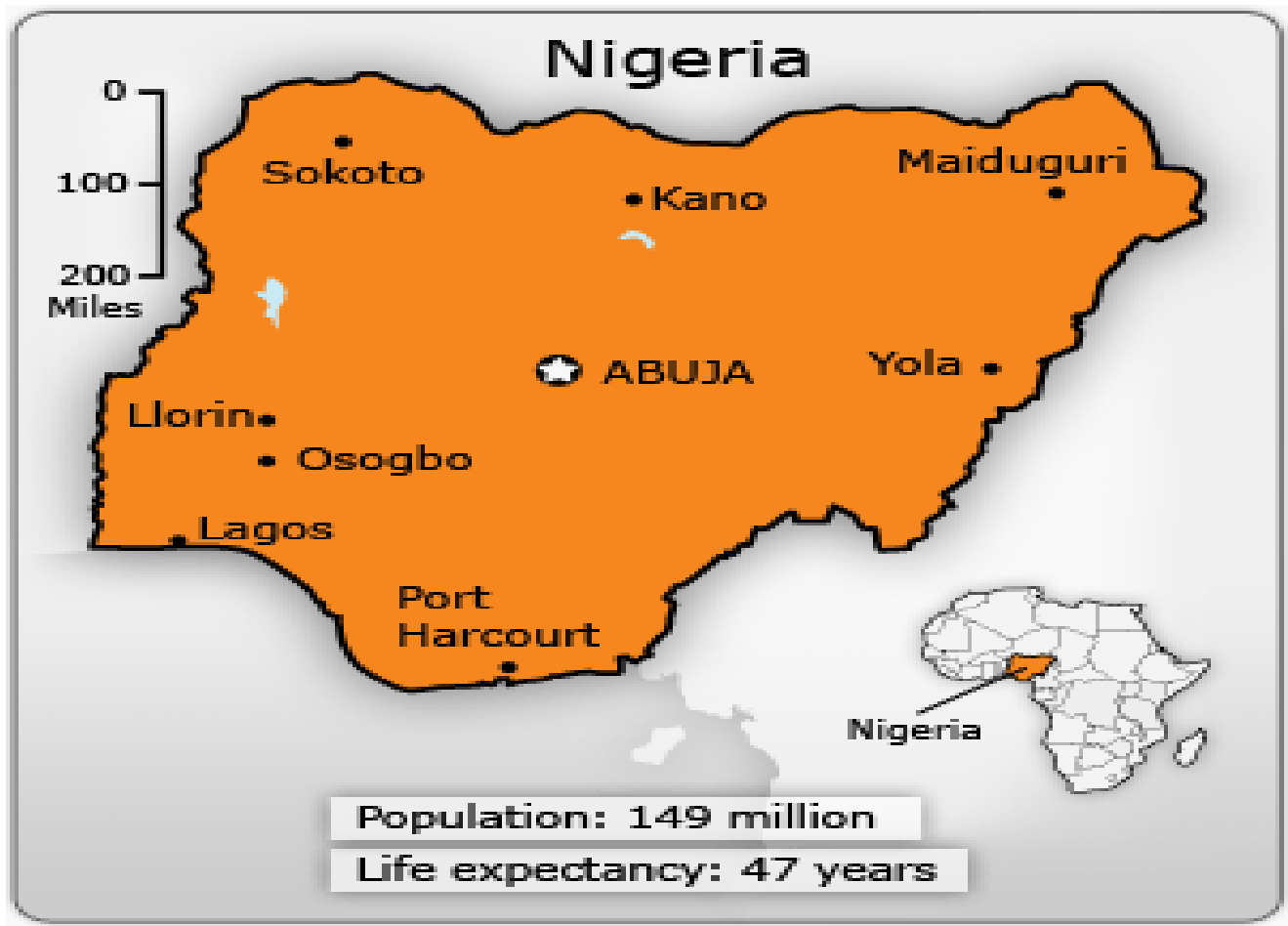

Figure 1a: Map of Nigeria and the Study Area: Kano

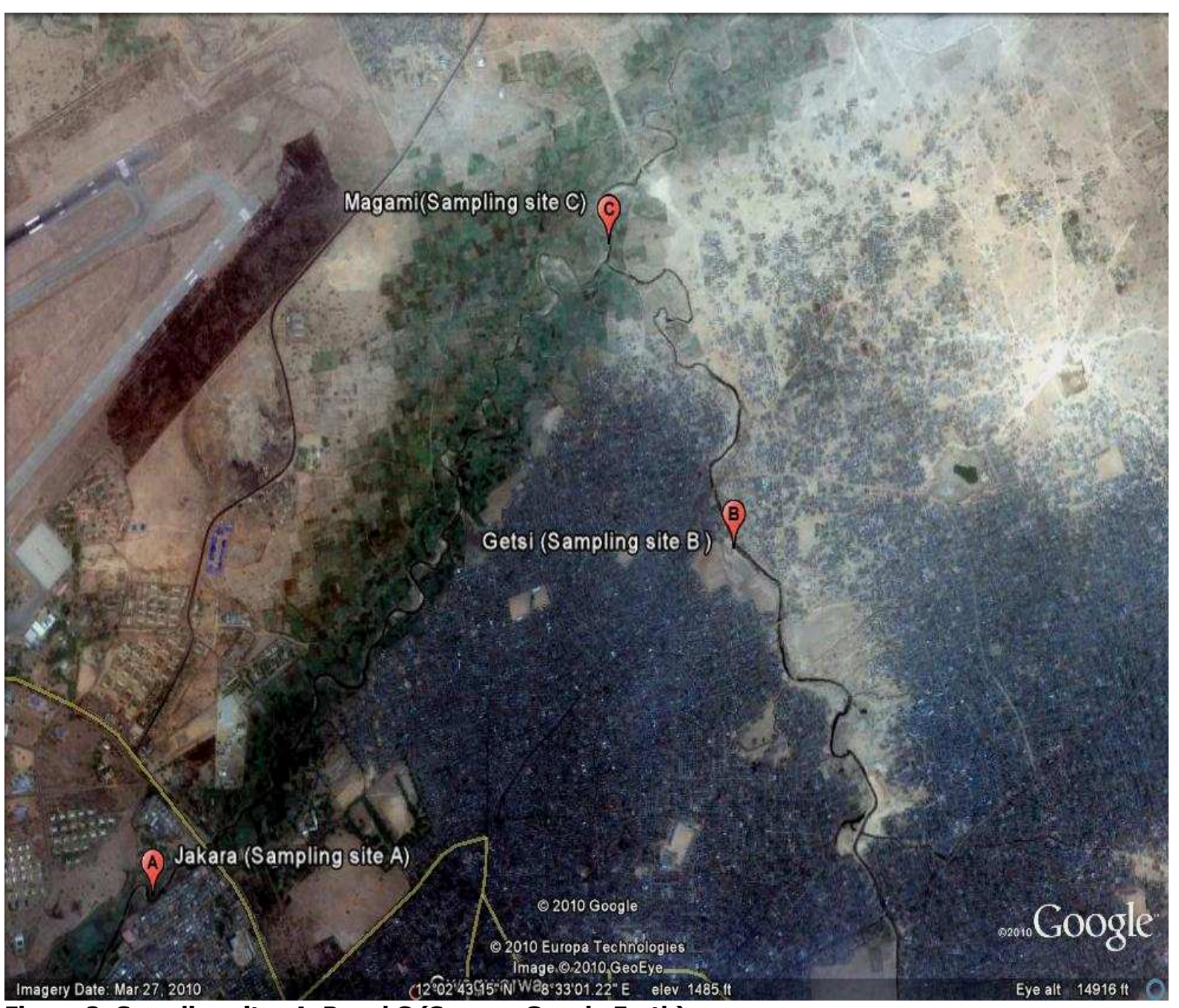

Figure 2: Sampling sites A, B and C (Source: Google Earth) 


\section{RESULTS AND DISCUSSION}

Results obtained in the study on spatial and temporal variations of zooplanktonic fauna in Jakara-Getsi River systems showed. Highest species richness of 20 at site $A$, with 13 as the least species richness observed at site $C$ (Table 1). Sarcodina sp. Showed highest distribution and abundance of $1016.34 \mathrm{org} / \mathrm{L}$, which was recovered at sites A, B, and C. Species richness according to taxa showed highest species richness of 11 among the Protozoa, with lowest richness of one species each among the Rotifera, and Nematoda (Table 1).

These results are in line with the discourse by Verma and Agarwal 2007), whereby organisms at the lowest trophic status have greater abundance (i.e. pyramid of numbers). Site $A$ had the overall highest zooplankton density of $691.28 \mathrm{org} / \mathrm{L}$ and the lowest record of 443.19 org/L was observed at site C (Table 2). Highest mean monthly zooplankton density was observed at in the month of February, $199.22 \mathrm{org} / \mathrm{L}$ at site A, $134.17 \mathrm{org} / \mathrm{L}$ at site $B$ and $138.22 \mathrm{org} / \mathrm{L}$ at site C. Lowest mean monthly zooplankton density was observed in different months at different sites at site $A, 12.2 \mathrm{org} / \mathrm{L}$ was observed in the month of July, whereas at site $B, 16.26$ org/L was recorded to be the lowest in the month of October. In the case of site C, $12.2 \mathrm{org} / \mathrm{L}$ was recorded in the months of June, August and October (Tables 2 and 3).

There is an observed bimodal fluctuation in zooplankton density at the three sites. At site site $A$, double maxima were recorded in the months of February and December, $199.3 \mathrm{org} / \mathrm{L}$ and $109.77 \mathrm{org} / \mathrm{L}$ respectively. At site B, there were observed maxima of in the months of February and April, $138.22 \mathrm{org} / \mathrm{L}$ and $60.97 \mathrm{org} / \mathrm{L}$ respectively (Tables 2 and 3 ). Highest distribution is observed among four zooplanktonic taxa which are the Protozoa, Insecta, Annelida and Cladocera recovered at all the three sites (Table 1; Figure 3).

Percent composition of zooplanktonic fauna based on their species richness, Protozoa predominated (37.9\%), with lowest percent composition among the Rotifer, Trematoda and Nematoda, with 3.5\% (Figure 3). Physicochemical analysis showed varying degrees of fluctuations along the temporal scale, where highest recorded mean monthly temperature was $32.0^{\circ} \mathrm{C}$ at sites $\mathrm{A}$ and $\mathrm{B}$, and $31.0^{\circ} \mathrm{C}$ at site $\mathrm{C}$ in the month of March (Table 2). Lowest mean monthly temperature was recorded in the month of December. With highest annual mean monthly temperature at site $\mathrm{B}, 25.0^{\circ} \mathrm{C}$, and lowest at site $\mathrm{C}, 24.3^{\circ} \mathrm{C}$ (Table 2). Despite the fluctuations temperature values obtained in this study period are within the FEPA (1991) regulation limit for effluent discharge into surface water, which is below $40.0^{\circ} \mathrm{C}$. the observed highest temperature in the month of March indicates seasonal variation in which is one of the driest characterized by high temperature, while coolest month was December, that falls within the Harmattan (Ezra, 2000; Kabiru, 2007).

The result of $\mathrm{pH}$ showed that the month of December had the highest $\mathrm{pH}$ at sites $\mathrm{B}$ and $\mathrm{C}, 8.4$ and 8.6 respectively, but least $\mathrm{pH}$ was recorded during the month of January. With pH of $6.1,6.2$ and 6.3 at sites A, B, and $C$ respectively (Table 2 ). The result falls within the FEPA (1991) and Ragnar (2004) limits range of 6.0-9.0. mean annual $\mathrm{pH}$ was highest at sites $\mathrm{B}$ and $\mathrm{C}, 7.7$ each, and lowest $\mathrm{pH}$ of 7.5 recorded at site $\mathrm{A}$ (Table 2). The water clarity (i.e. transparency) recorded at three sites was very low, while highest mean transparency was $24 \mathrm{~cm}, 21 \mathrm{~cm}$ and $27 \mathrm{~cm}$ at sites $A$ in the month of June, B and C respectively. Lowest mean monthly transparency readings were obtained in the month of January at sites A and B with $3.5 \mathrm{~cm}$ and $5.5 \mathrm{~cm}$ respectively and lowest at site $C$ in the months of April and May of $1.0 \mathrm{~cm}$ (Table 2). All these readings are below the recommended range of $3.0-3.5 \mathrm{~cm}$ necessary effective growth, reproduction and distribution of zooplanktons (Hart, 1986). Annual mean transparency was highest at site $C, 15.9 \mathrm{~cm}$ and lowest at site $A$, $14.6 \mathrm{~cm}$ (Table 2).

Annual mean dissolved oxygen (DO) of $5.3 \mathrm{mg} / \mathrm{L}$ was the highest recorded at site $A$, with lowest annual mean of $4.3 \mathrm{mg} / \mathrm{L}$ observed at site B (Table 3 ). Highest monthly means were recorded in the months of March, where $5 . \mathrm{mg} / \mathrm{L}, 10.5 \mathrm{mg} / \mathrm{L}$ and $6.0 \mathrm{mg} / \mathrm{L}$ were recorded at sites $\mathrm{A}$, $B$ and $C$ (Table 3 ). While lowest readings of $1.1 \mathrm{mg} / \mathrm{L}$, $1.0 \mathrm{mg} / \mathrm{L}$ and $1.0 \mathrm{mg} / \mathrm{L}$ were recorded during the month of July at sites A, B and C Table 3). The overall annual 5day Biochemical oxygen demand $\left(\mathrm{BOD}_{5}\right.$ mean showed water quality within the beta-mesosaprobic class, which is the type of water body with a moderate amount of organic loading (Zlacedek and Tucek, 1975). It is also worthy of note that highest BOD monthly mean was observed in the month within the dry season (i.e. March and December), this is line with the observations made by Bichi and Anyata (1999) and that Jakara River during the dry season is almost composed of sewage water. Electrical conductivity (EC) results showed highest monthly means of $3890 \mu \mathrm{S} / \mathrm{cm}$ recorded in the month of March at site A, $3600 \mu \mathrm{S} / \mathrm{cm}$ was recorded during the months of February and May at site B and $3850 \mu \mathrm{S} / \mathrm{cm}$ observed at site $C$ in the month February. Highest annual mean of $2748.3 \mu \mathrm{S} / \mathrm{cm}$ was obtained at site A (Table 3 ). All the overall means, both monthly and annually are beyond the FEPA (1991) and Lenntech (2008) recommended limit of $<2000 \mu \mathrm{S} / \mathrm{cm}$. This result is in agreement with the work of Mustapha (2008), conducted in the basin where all the recorded EC results were above $2000 \mu \mathrm{S} / \mathrm{cm}$. table 4 illustrates seasonal abundance of zooplanktons, in which dry season is recorded to have higher mean zooplankton density as compared with the wet season, $5.62 \mathrm{org} / \mathrm{l}$ and $28.0 \mathrm{org} / \mathrm{L}$ respectively, with site $A$ having the highest mean annual zooplankton density of $71.37 \mathrm{org} / \mathrm{L}$. reason to this discrepancy could be deduced to the fact rain water dilute the overall aquatic system, and thus abundance of the zooplankton community in a given volume will lower as such. Also the fact that the study area is a river system, the surface runoff during and after rainfall would increase the water volume and consequently flow, bearing in mind that zooplankton are floating organisms, thus they go with flow (Maiti, 2004; Imam, 2010). Kendall's tau-b correlation between physico-chemical parameters showed positive correlation between Electrical conductivity and Total dissolved solid at P $\leq 0.01$ (2-tailed), there was also positive correlation between Dissolved oxygen and transparency, likewise between Oxygen saturation and transparency, at $\mathrm{P} \leq 0.05$ (2-tailed). There was negative correlation between Electrical conductivity and $\mathrm{pH}$, and also between Total dissolved solids and $\mathrm{pH}$ at $\mathrm{P} \leq 0.01$ (2tailed). There was positive Kendall's tau-b correlation of zooplankton density between sites $A$ and $B[r=0.836$, $P \leq 0.01$ (2-tailed)]. Likewise between sites $A$ and $C$ $[r=0.783, P \leq 0.01$ (2-tailed)]. 
Table 1: Zooplankton Abundance and Distribution in the Jakara-Getsi River System, Kano, Nigeria.

\begin{tabular}{|c|c|c|c|c|c|}
\hline S/NO. & TAXON & SITE A & SITE B & SITE C & Total (Org/L) \\
\hline & PROTOZOA & & & & \\
\hline 1 & Arcella vulgaris & 4.07 & 12.21 & - & 16.28 \\
\hline 2 & Bodo caudatum & 4.07 & - & - & 4.07 \\
\hline 3 & Chroomonas caudata & 4.07 & - & - & 4.07 \\
\hline 4 & Euglena spp. & 24.41 & - & 4.07 & 28.48 \\
\hline 5 & Glaucoma scintillans & 40.65 & 16.26 & 12.2 & 69.11 \\
\hline 6 & Gonium pectorale & 4.07 & - & - & 4.07 \\
\hline 7 & Paramecium spp. & - & - & 8.14 & 8.14 \\
\hline 8 & Sarcodina spp. & 365.92 & 349.59 & 300.83 & 1016.24 \\
\hline 9 & Spirostonum ambiguum & 60.99 & 24.39 & 20.34 & 105.72 \\
\hline 10 & Stentor spp. & - & 4.07 & - & 4.07 \\
\hline \multirow[t]{2}{*}{11} & Stylonychia mytilus & 4.07 & - & - & 4.07 \\
\hline & INSECTA & & & & \\
\hline 12 & Anopheles spp. Larva & - & 4.07 & 8.14 & 12.21 \\
\hline 13 & Anopheles spp. Pupa & 4.07 & - & - & 4.07 \\
\hline 14 & Chironomus spp. larva & - & 4.07 & - & 4.07 \\
\hline 15 & Simulium spp. Larva & 4.07 & - & - & 4.07 \\
\hline 16 & Triaenodes spp. Larva & - & - & 4.07 & 4.07 \\
\hline 17 & Culex spp. Pupa & - & - & 4.07 & 4.07 \\
\hline \multirow[t]{2}{*}{18} & Leptocerus spp. Larva & - & 4.07 & - & 4.07 \\
\hline & ROTIFERA & & & & \\
\hline \multirow[t]{2}{*}{19} & Brachionus urceus & 4.07 & - & - & 4.07 \\
\hline & NEMATODA & & & & \\
\hline \multirow[t]{2}{*}{20} & Hemicycliophora spp. & - & 4.07 & - & 4.07 \\
\hline & ANNELIDA & & & & \\
\hline 21 & Haplotaxis gordoides & 40.66 & 36.61 & 36.59 & 113.86 \\
\hline 22 & Herpobdella octoculata & 12.21 & 16.27 & 16.26 & 44.74 \\
\hline \multirow[t]{2}{*}{23} & Rhabdolaimus aquaticus & 24.4 & - & 4.07 & 28.47 \\
\hline & CLADOCERA & & & & \\
\hline 24 & Daphnia pulex & 20.34 & 20.34 & 20.34 & 61.02 \\
\hline 25 & Bosmina longinostris & 8.13 & - & - & 8.13 \\
\hline \multirow[t]{2}{*}{26} & Polyphemus pediculus & - & 4.07 & - & 4.07 \\
\hline & TREMATODA & & & & \\
\hline 27 & $\begin{array}{l}\text { Planaria gonocephala } \\
\text { COPEPODA }\end{array}$ & 8.13 & - & 4.07 & 12.2 \\
\hline 28 & Cyclops spp. & 4.07 & - & - & 4.07 \\
\hline \multirow[t]{3}{*}{29} & Metanauplius larva & 8.14 & 16.27 & - & 24.41 \\
\hline & Total (Org/L) & 691.28 & 520.43 & 443.19 & 1654.9 \\
\hline & Spp Richness & 20 & & & \\
\hline
\end{tabular}


Bajopas Volume 4 Number 2 December, 2011

Table 2: Temperature, pH, Transparency and Zooplankton Density of Jakara-Getsi River System, Kano, Nigeria.

\begin{tabular}{|c|c|c|c|c|c|c|c|c|c|c|c|c|}
\hline \multirow[t]{2}{*}{ Month } & \multicolumn{3}{|c|}{ Temperature $\left({ }^{\circ} \mathrm{C}\right)$} & \multicolumn{3}{|c|}{$\mathrm{pH}$} & \multicolumn{3}{|c|}{ Transparency $(\mathrm{cm})$} & \multicolumn{3}{|c|}{ Zooplankton density (Org/L) } \\
\hline & Site A & Site B & Site C & Site A & Site B & Site C & Site A & Site B & Site C & Site A & Site B & Site C \\
\hline January & 22 & 21 & 23 & 6.1 & 6.2 & 6.3 & 3.5 & 5.5 & 11 & 16.3 & 24.4 & 16.27 \\
\hline February & 22.2 & 22.3 & 21.5 & 7.6 & 8.1 & 7.8 & 10 & 12.5 & 13 & 199.3 & 134.13 & 138.22 \\
\hline March & 32 & 32 & 31 & 6.5 & 6.6 & 6.5 & 12 & 21 & 27 & 52.88 & 20.33 & 24.4 \\
\hline April & 31 & 30 & 27 & 7.4 & 8 & 8 & 14 & 14 & 9 & 60.99 & 23.2 & 60.97 \\
\hline May & 25 & 27 & 24 & 7.6 & 7.8 & 7.9 & 11 & 10 & 9 & 81.32 & 36.6 & 56.99 \\
\hline June & 22 & 23 & 23 & 7.5 & 7.7 & 7.6 & 24 & 12 & 14 & 44.74 & 24.4 & 12.2 \\
\hline July & 23 & 25 & 24 & 7.7 & 8 & 7.7 & 18 & 17 & 17 & 12.2 & 36.6 & 20.33 \\
\hline August & 24 & 24 & 24 & 7.5 & 7.6 & 7.5 & 20 & 20 & 18 & 20.33 & 20.33 & 12.2 \\
\hline September & 26 & 27 & 26 & 8 & 8 & 8.5 & 19 & 18 & 20 & 40.66 & 24.4 & 32.53 \\
\hline October & 24 & 24 & 24 & 7.9 & 7.9 & 7.9 & 7.6 & 19.6 & 13 & 16.26 & 16.26 & 12.2 \\
\hline November & 24 & 24 & 24 & 7.9 & 8 & 8 & 14.6 & 15.7 & 15.9 & 36.6 & 48.8 & 16.27 \\
\hline December & 18.8 & 20.6 & 19.6 & 8 & 8.4 & 8.6 & 109.77 & 60.99 & 36.59 & 109.77 & 60.99 & 36.59 \\
\hline Mean & 24.5 & 25 & 24.3 & 7.5 & 7.7 & 7.7 & 57.7 & 39.2 & 36.6 & 57.7 & 39.2 & 36.6 \\
\hline
\end{tabular}

Table 3: Dissolved Oxygen, Biochemical Oxygen Demand, Electrical Conductivity and Zooplankton density of Jakara-Getsi River System, Kano, Nigeria.

\begin{tabular}{|c|c|c|c|c|c|c|c|c|c|c|c|c|}
\hline \multirow[t]{2}{*}{ Month } & \multicolumn{3}{|c|}{ Dissolved Oxygen (Org/L) } & \multicolumn{3}{|c|}{ 5-Day BOD (mg/L) } & \multicolumn{3}{|c|}{ El.conductivity(uS/cm) } & \multicolumn{3}{|c|}{ Zooplankton density (Org/L) } \\
\hline & Site A & Site B & Site C & Site A & Site B & Site C & Site A & Site B & Site C & Site A & Site B & Site C \\
\hline January & 5 & 4.2 & 3 & 3 & 1.8 & 2.2 & 2440 & 3390 & 3460 & 16.3 & 24.4 & 16.27 \\
\hline February & 4 & 4.7 & 2.8 & 2.9 & 2 & 1 & 3180 & 3600 & 3880 & 199.3 & 134.13 & 138.22 \\
\hline March & 5.9 & 10.5 & 6 & 3.9 & 4.9 & 3.6 & 3890 & 3260 & 3850 & 52.88 & 20.33 & 24.4 \\
\hline April & 4.5 & 3.9 & 3.8 & 4.2 & 2.7 & 3 & 3330 & 3710 & 1575 & 60.99 & 23.2 & 60.97 \\
\hline May & 4 & 3.6 & 2.8 & 3.4 & 2.3 & 1.3 & 2750 & 3600 & 3000 & 81.32 & 36.6 & 56.99 \\
\hline June & 5.3 & 2.3 & 2.2 & 1.4 & 1 & 1.1 & 1580 & 1860 & 1930 & 44.74 & 24.4 & 12.2 \\
\hline July & 4 & 1.7 & 4.9 & 1.1 & 1.3 & 1.9 & 2250 & 1140 & 1670 & 12.2 & 36.6 & 20.33 \\
\hline August & 5.6 & 3 & 5 & 3 & 2 & 2.2 & 1880 & 1000 & 1400 & 20.33 & 20.33 & 12.2 \\
\hline September & 6 & 5 & 5.6 & 2 & 2 & 3 & 1750 & 980 & 1350 & 40.66 & 24.4 & 32.53 \\
\hline October & 4.5 & 4 & 4.2 & 2.5 & 2 & 2 & 3100 & 2100 & 2940 & 16.26 & 16.26 & 12.2 \\
\hline November & 5.3 & 4.2 & 4.2 & 2 & 2.9 & 2.3 & 3220 & 2990 & 2990 & 36.6 & 48.8 & 16.27 \\
\hline December & 10 & 4.3 & 4.5 & 4.6 & 3 & 2.4 & 3610 & 2520 & 3000 & 109.77 & 60.99 & 36.59 \\
\hline Mean & 5.3 & 4.3 & 4.4 & 2.8 & 2.3 & 2.2 & 2748.3 & 2512.5 & 2587.08 & 57.7 & 39.2 & 36.6 \\
\hline
\end{tabular}


Bajopas Volume 4 Number 2 December, 2011

Table 4: Seasonal Zooplankton Abundance of Jakara-Getsi River System, Kano, Nigeria.

\begin{tabular}{|c|c|c|c|c|c|c|c|c|c|}
\hline \multirow[t]{2}{*}{ Site } & \multicolumn{3}{|c|}{$\begin{array}{l}\text { Dry Season } \\
\text { Zooplankton density } \\
\text { (Org/L) }\end{array}$} & \multicolumn{3}{|c|}{$\begin{array}{l}\text { Wet Season } \\
\text { Zooplankton density } \\
\text { (Org/L) }\end{array}$} & \multicolumn{3}{|c|}{$\begin{array}{l}\text { Annual } \\
\text { Zooplankton density } \\
\text { (Org/L) }\end{array}$} \\
\hline & Mean & Std Dev & Maxi & Mean & Std Dev & Maxi & Mean & Std Dev & Maxi \\
\hline A & 71.8 & 65.4 & 199.12 & 35.91 & 25.89 & 81.2 & 71.37 & 168.38 & 516.19 \\
\hline B & 58.27 & 46.18 & 138.2 & 24.39 & 11.21 & 36.59 & 53.4 & 125.64 & 386.8 \\
\hline C & 48.91 & 46.91 & 138.2 & 23.71 & 18.43 & 56.9 & 45.64 & 110.17 & 337.53 \\
\hline Mean & 59.62 & 52.83 & 158.51 & 28.0 & 18.51 & 58.23 & 56.8 & 134.73 & 413.51 \\
\hline
\end{tabular}

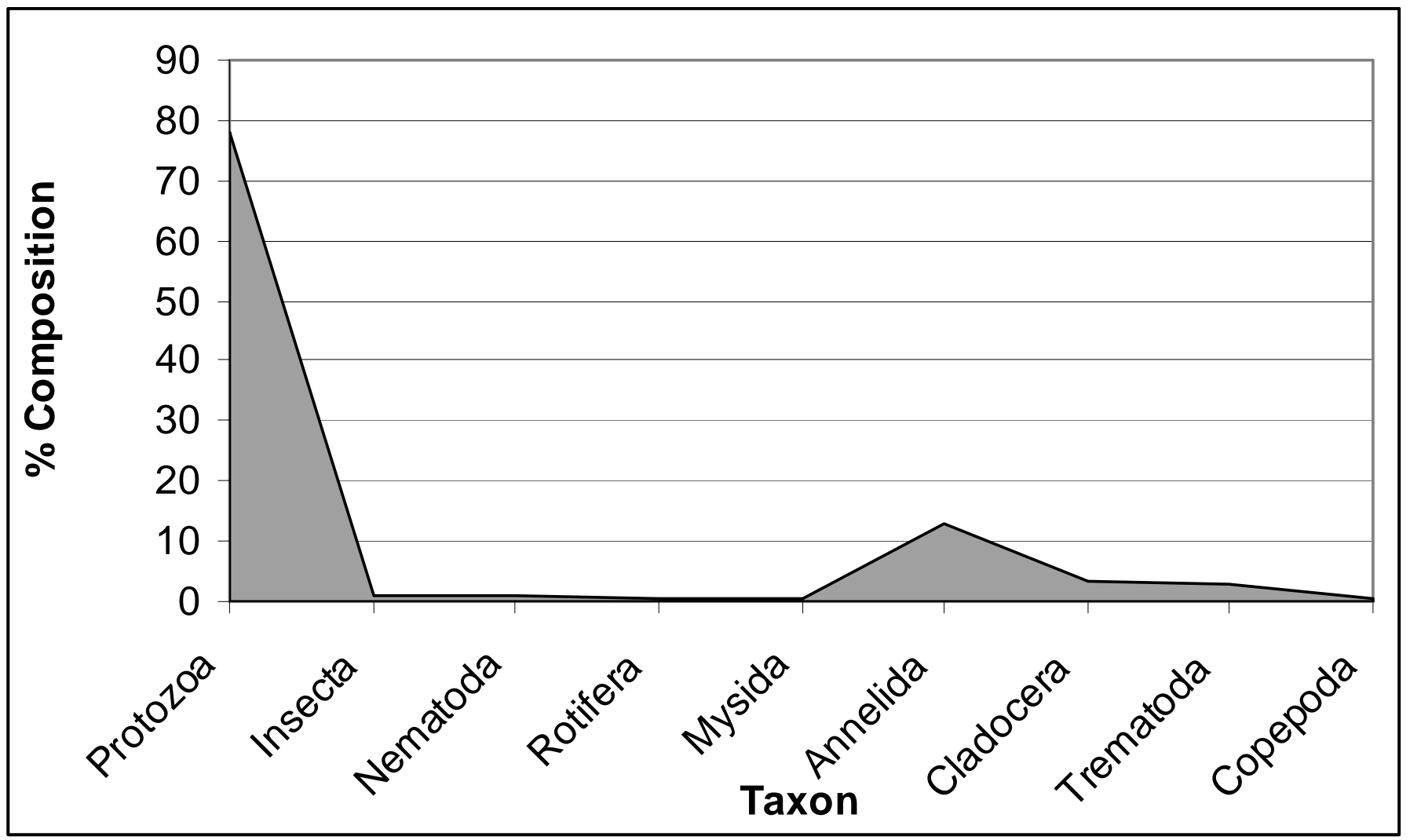

Figure 3: Zooplankton Percent Composition according to Species Richness 


\section{Conclusion and Recommendations}

This study highlights the state of Jakara-Getsi river system in terms of zooplanktonic fauna composition and distribution. The overall abundance of zooplanktons was observed to be low both spatially and temporally. There is the prolem of maintaining the balance of the aquatic ecosystem bearing mind that the study area is part of the Bompai-Jakara catchment

\section{REFERENCES}

Allaby, M. (1999): Jaccard' Index In: Dictionary of Zoology. Available on http://www.encyclopedia.com

APHA(2005): Standard Methods for the Examination of Water and Wastewater. 21 $1^{\text {st }}$ edition, eds. Eaton, A.D., Clescer, L.S., Rice, E.N. and Greenberg, A.E. Port City Press, Baltimore, USA.

Bichi, M.H. (1993): Environmental Pollution in Kano In: The Contribution of Wastewater Discharges from bompai, Sharada, and Challawa industrial estates. Proceeding of Scientific Association of Nigeria, 1993, Bayero University Kano.

Bichi, M.H. and Anyata, B.U. (1999): Industrial Waste Pollution in Kano River basin. Environ. Management \& Health. 10(2): 112-116.

Binns, T., Maconachie, R.A. and Tanko, I.A. (2003): Water, Land and Health in Urban and Periurban Food Production: The Case Study of Kano, Nigeria. Land Degradation \& Development. 14(5): 431-444.

Ezra, A.G. (2000): A Study of Planktonic Algae in Relation to the Physicochemical properties of some Freshwater Ponds in Bauchi, Nigeria. Nig. J. Exptl Appl. Biol. 1(2): 55-60.

FEPA(1991): National Environmental Protection (Effluent Limitations) Regulations of 1991. Federal Environmental Protection Agency, Lagos, Nigeria, Ref. No. S.18.

Google Earth (2010) My Places: Kano, Nigeria. Available on www.google.com, accessed 20/01/2010.

Hanna Instruments (2004): Instruction Manual: HI 146 Portable Water Proof Microprocessor Dissolved Oxygen, pH/EC/TDS meters. Hanna Instruments, Canada, pp: 1-19. www.hanna.com

Howick, G.L. and Wilhm, J. (1984): Zooplankton and Benthic Macroinvertebrates in Lake Carl Blackwell. Proc. Oklah. Acad. Scie. 64: 63-65.

Hart, R.L. (1986): Aspects of the Feeding Ecology of Turbid Water Zooplanktons, in situ Studies of Community Filtration Rates in Silt-laden Lake le Roux, Orange River, South Africa. J.Plankton Res. 8(3): 401-426.

Imam, T.S. (2010): Aspects of Ecology and Biomonitoring of Heavy Metals associated basin, where fishing is notably practised, and the fact that trophic status of zooplanktons cannot be substituted. Thus, effort of monitoring as well as government enforcement of FEPA effluent and sewage discharge regulation limits need to effected. This is in order to improve the health of the aquatic biodiversity which is will be ecologically and socio-economically beneficial to Kano populace and the nation in general.

with Industrial Pollution in the Bompai-Jakara Catchment Basin, Kano state, Nigeria. PhD Progress Seminar conducted at Biological Sciences Department, Bayero University Kano, on $24^{\text {th }}$ February, 2010 (Unpublished).

Kabiru, A. (2007): The Kano Physical Environment. Department of Geography, Bayero University Kano available on http://www.kanoonline.com, accessed 12/01/2008

Lenntech (2008): Water Treatment. Published by Lenntech. Rotterdam, Netherlands. www.excelwater.com/thp/filters/waterpurifica tion.htm

Maiti, S.K. (2004): Handbook of Methods in Environmental Studies: Water and Wastewater Analysis, ABD Pub., Jaipur, India, Vol. I, pp: 242-266.

Margalef, R. (1958): Information Theory in Ecology, Gen. Syst. 3:36-71.

Mukhtar, M.D., Indabawa, I.I. and Imam, T.S. (2010): Public Health Implications of Sewage Ponds in kano Metropolis, Nigeria. J.Food Agric. Environ. 8(2): 25-31, www.wworld-food.net, Helsinki, Finland.

Mustapha, A. (2008): Environmental Pollution in Kano: the contribution of Wastewater Discharge from Old City and Bompai industrial estate to Jakara River Basin System. Tech Science Journal. 2(1): 83-88.

Ragnar, R. (2004): Environmental Load, CharnetAquafarmer, www.holar.is/aquafarmer, accessed 05.08.2009.

SDR-IV (2010): Species Diversity and Richness, 4:3910, Pisces Conservation Ltd, http://www.pisces-conservation.com/sdr

Verma, P.S. and Agarwal, V.K. (2007): Environmental Biology: Principles of Ecology. $11^{\text {th }}$ Reprinted Edition, S.Chand \& Co. Ltd, New Delhi, India. Pp: 3-530.

WRECA (1990): Water resources and Engineering Construction Agency, Kano state, Nigeria.

Zelinka, M. and Marvan, P. (1961): Zur Praziensierung der biologischen Klassifikation der Reinheit Fleissender Gewasser, Arch. Hydrobiol.57: 389 (English Translation).

Zlacedek, V. and Tucek, F. (1975): Relation of the Saprobic Index to BOD. Water Res. 9(9): 791-794. 